\title{
Antimicrobial, antioxidant, anti- inflammatory and cytotoxic study of extracts of Guibourtia tessmanii (harms) J. Léonard from Gabon
}

Cédric Sima Obiang ${ }^{1,2^{*}}$ D, Rick Léonid Ngoua Meye Misso ${ }^{1,2}$, Guy Roger Ndong Atome ${ }^{1,2}$, Rany Berty Mbeng Obame ${ }^{1,2}$, Joseph Privat Ondo ${ }^{1,2}$, Louis Clément Obame Engonga ${ }^{1,2}$ and Edouard Nsi Emvo ${ }^{1}$

\begin{abstract}
Background: Gabonese flora abounds in a significant reserve of plants in medical matter. Thus, medicinal plants occupy a significant place in African pharmacopeia. Aim of this work was to evaluate the antimicrobial, antioxidant, anti-inflammatory and cytotoxic properties of extracts of Guibourtia tessmanii (Harms) J. Léonard.

Methods: The test for sensitivity to microorganisms was performed by the diffusion method, while the MICs and MBCs were evaluated by the microdilution technique. Antioxidant tests were performed by scavenging the DPPH and ABTS radicals. Anti-inflammatory activity was determined by protein denaturing and membrane stabilization methods. The cytotoxicity was evaluated on the tadpoles of the green frog.

Results: The antibacterial activity shows that the Gt F2 fraction and the water-acetone extract produced the greatest inhibitions. The water, water-ethanol and water-acetone extracts exhibited bactericidal effects on the majority of bacteria. In the case of trapping of the DPPH radical, the $I_{50}$ values varied from $6.92 \pm 0.48$ to $16.64 \pm$ $0.20 \mathrm{\mu g} / \mathrm{mL}$. For the decolouration of ABTS, oxidation was mainly inhibited by the water-acetetone, water-ethanol extracts and some fractions. The water and water-acetone extracts showed good inhibition of denaturation. The hemolysis test confirmed the good activities of the extracts. The lethal test showed that the $\mathrm{LC}_{50}$ drops from $171.37 \pm 9.25$ to $58.25 \pm 7.21 \mu \mathrm{g} / \mathrm{mL}$ after 24 and $96 \mathrm{~h}$ of exposure. In tadpoles exposed to $7.81 \mathrm{\mu g} / \mathrm{mL}$ of extracts, the first mortalities (12.5\%) were observed on the second day of exposure. From the ninth day, the mortality rate increased (25\%) until the 16th day.
\end{abstract}

Conclusion: Our results show that Guibourtia tessmanii may be a promising product for the isolations of molecules responsible for biological activities.

Keywords: Antimicrobial, Antioxidant, Anti-inflammatory, Cytotoxic, Guibourtia tessmanii (harms) J. Léonard

\footnotetext{
*Correspondence: cedricsima@gmail.com; cedricsima@univ-masuku.ga

'Laboratory of Research in Biochemistry, University of Sciences and

Technology of Masuku, P. O. Box 943, Franceville, Gabon

${ }^{2}$ Laboratory of Natural Substances and Organometallic Synthesis, University

of Sciences and Technology of Masuku, P. O. Box 943, Franceville, Gabon
}

\section{Springer Open}

(C) The Author(s). 2021 Open Access This article is licensed under a Creative Commons Attribution 4.0 International License, which permits use, sharing, adaptation, distribution and reproduction in any medium or format, as long as you give appropriate credit to the original author(s) and the source, provide a link to the Creative Commons licence, and indicate if changes were made. The images or other third party material in this article are included in the article's Creative Commons licence, unless indicated otherwise in a credit line to the material. If material is not included in the article's Creative Commons licence and your intended use is not permitted by statutory regulation or exceeds the permitted use, you will need to obtain permission directly from the copyright holder. To view a copy of this licence, visit http://creativecommons.org/licenses/by/4.0/. 


\section{Introduction}

Guibourtia tessmanii (Harms) J. Léonard (Family: Fabaceae) is a medicinal plant used in Central Africa for the treatment of infectious diseases, worms and cardiovascular diseases [1] [2]. Infectious diseases of microbial origin are diseases caused by the development of bacteria or yeasts, some species of which are pathogenic [3]. During the last decade, great interest has been shown in the study of microbes, from a biological, nosological and therapeutic point of view. This importance given to the study of microbial diseases follows the appearance of resistance of strains to the most commonly used drugs [4].

Inflammation is an immune defense process of the body in response to an attack, the goal of which is to eliminate the pathogen and repair tissue damage [5]. At the tissue level, the inflammatory response is characterized by increased vascular permeability, increased protein denaturation and alteration of cell membranes. Inflammation is considered to be an important source of oxygen radicals produced directly by activated phagocytic cells during phagocytosis. Inflammation accelerates the production of oxygen species and decreases the antioxidant defense capacity, promoting the appearance of oxidative stress, an important factor in the development of neurodegenerative, cardiovascular and cancer diseases [6].

Medicinal plants are used in Africa as remedies for the treatment of various diseases because they contain components rich in therapeutic principles [7]. Gabon, with an exceptional biodiversity constitutes a vast reservoir of unexplored potential active molecules. As part of the valuation of the Gabonese flora, this study highlights the pharmacological and cytotoxic properties of a plant used in Gabon for microbial infections.

\section{Material and methods}

\section{Chemicals, reagents and media}

Dimethyl sulfoxide, quercetin, 1,1-diphenyl-2-picryl hydrazyl, 2, 2' -azinobis (3-ethylbenzthiazoline-6-sulfonic acid and Folin Ciocalteu reagent were purchased from FlukaChemika (Switzerland). Gallic acid, butylated hydroxyanisole (BHA) and other chemicals were from Sigma Chemical (Sigma-Aldrich Co., St. Louis, MO, USA). All chemicals used were of analytical grade.

\section{Preparation of samples}

The plant material (stem bark of Guibourtia tessmanii) was collected in Oyem (northern Gabon), in June 2017 and identified in the National Herbarium (IPHAMETR A). The voucher specimen (SOC26: Guibourtia tessmanii) was deposited at the national Herbarium. The harvested bark was dried, crushed and used for extractions.

The water-ethanol $(30 / 70, v / v)$, water-acetone $(30 / 70$, $\mathrm{v} / \mathrm{v})$ and water (100\%) extracts were prepared from the dry powder of Guibourtia tessmanii. Each sample (25 g) was mixed with $250 \mathrm{~mL}$ of appropriate solvents. The aqueous extracts were boiled for $60 \mathrm{~min}$. All extracts were filtered, concentrated and lyophilized. The extracts obtained were stored at $4{ }^{\circ} \mathrm{C}$. until they were used for the various tests.

The different partitioned extracts (fractions) were obtained by flash chromatography as a function of the increasing polarity gradient. The dichloromethane/ methanol solvent system (1:0-0:1) was chosen as the elution mode, varying in each case the polarity of the solvent. The fractions of the same nature were grouped together by the thin layer chromatography method.

\section{Bacterial germs tested}

The bacterial carrier used in our study consisted of six reference bacterial strains (Escherichia coli 105182 CIP, Listeria innocua LMG 135668 BHI, Staphylococcus aureus ATCC 25293 BHI, Enterococcus faecalis 103907 CIP, Bacillus cereus LMG 13569 BHI, Shigella dysenteria 5451 CIP) and three clinical strains are Pseudomonas aeruginosa, Salmonella enterica and Salmonella typhi,

\section{Antibacterial activity}

The diffusion method has been used to study the sensitivity of microorganisms to plant extracts. Bacterial colonies were used to prepare the inoculum in order to have a density equivalent to that of $0.5 \mathrm{McF}$ arland. The flood inoculated agar was left for $10 \mathrm{~min}$. Wattman 1 paper discs, sterilized and impregnated with a concentration of extract $(100 \mu \mathrm{g} / \mathrm{mL})$, were placed on the agar plate. Petri dishes were incubated for $18-24 \mathrm{~h}$ at $37^{\circ} \mathrm{C}$. Gentamicin, Ampicillin, Tetracycline, Amoxicillin and Doxycycline were used as positive controls.

The minimum inhibitory concentrations (MICs) of crude extracts and fractions were determined by the microdilution method on 96-well microplates [8]. A series of seven dilutions of each extract (double dilutions ranging from 0.0049 to $5 \mathrm{mg} / \mathrm{ml}$ ) were made in Muller Hinton Nutrient Broth (Liofilchem, Italy).

To determine the minimum bactericidal concentration, nutrient agar was inoculated with $100 \mu \mathrm{L}$ of the contents of the wells (concentrations greater than or equal to MIC). The MBC is determined after a $24 \mathrm{~h}$ incubation at $37^{\circ} \mathrm{C}$.

Antibacterials were considered to be bactericidal, those with MBC / MIC ratios equivalent to 1 or 2 and bacteriostatic if the MBC / MIC ratio was equivalent to 4 or $16[8,9]$.

\section{Antioxidant activity assay DPPH (Diphenyl-2-picrylhydrazyl) assay}

The measurement of the anti-radical activity was conducted according to the method of Blois [10] as 
described by Brand-Williams et al. [11]. Vit C (vitamin C) and BHA (Butylated Hydroxyanisole) were used as references. DPPH solutions are incubated for $30 \mathrm{~min}$ in the absence (control) or in the presence of increasing concentrations of plant crude extracts and fractions $(0.91,1.81,3.62,7.25,14.5,25,50$ and $100 \mu \mathrm{g} / \mathrm{mL})$. The absorbance at $517 \mathrm{~nm}$ was read and the antioxidant activity was calculated according to the following formula:

$\%$ Radical scavenger activity $=[($ Abs DPPH - Abs sample $) /$ Abs DPPH $] \times 100$

\section{ABTS (azinobis (3-ethylbenzothiazoline-6-sulfonate)) method}

The ABTS test is based on the ability of an antioxidant to stabilize the $\mathrm{ABTS}^{*+}$ radical by transforming it into $\mathrm{ABTS}^{+}$[12]. To $60 \mu \mathrm{L}$ of extract, $2.94 \mathrm{~mL}$ of $\mathrm{ABTS}^{\circ+}$ so- $^{\circ}$ lution were added. The mixture was incubated at $37^{\circ} \mathrm{C}$ for $20 \mathrm{~min}$ in the dark. Vit $\mathrm{C}$ and BHA were used as references. After incubation, the absorbance was measured in a spectrophotometer at $734 \mathrm{~nm}$. The percent inhibition (PI) was calculated by the following method:

\section{Percentage inhibition $=\left[\left(\mathrm{A}_{0}-\mathrm{A}\right) / \mathrm{A}_{0}\right] \times 100$}

$\mathrm{A}_{0}$ : Absorbance of $\mathrm{ABTS}^{+}$radical + ethanol, A: Absorbance of $\mathrm{ABTS}^{+}$radical + sample extract or standard.

\section{Anti-inflammatory activities}

\section{Anti-protein denaturation test}

This test was carried out according to the method used by Ngoua-Meye-Misso et al [13]. Briefly, a mixture of fresh chicken egg albumin (0.1 mL), pH 6.4 saline phosphate buffered saline $(0.9 \mathrm{~mL})$ and varying concentrations of the crude extracts and fractions $(1.9 \mathrm{~mL})$ was run so that endings become 31.25, 62.5, 125, 250 and $500 \mu \mathrm{g} / \mathrm{mL}$. Then, the mixtures were incubated at $37^{\circ} \mathrm{C}$ for $20 \mathrm{~min}$ and then heated at $70^{\circ} \mathrm{C}$ for $5 \mathrm{~min}$. Distilled water served as a negative control. The absorbances were measured at $660 \mathrm{~nm}$. Diclofenac sodium was used as a reference drug and similarly processed for the determination of absorbance.

$$
\begin{aligned}
\text { Inhibition }(\%)= & {[\text { (Abs sample-Abs control }) / \text { Abs control }] } \\
& \times 100
\end{aligned}
$$

Abs = absorbance, the concentration of the extract for $50 \%$ inhibition $\left(\mathrm{IC}_{50}\right)$ was determined by the doseresponse curve.

\section{Membrane stabilization test}

The membrane stabilization test was evaluated by the human red blood cell hemolysis (HRM) method. This hemolysis was induced on the one hand by heat on the other hand by distilled water [14] with some modifications.

\section{Preparation of the erythrocyte suspension}

Fresh whole blood ( $3 \mathrm{~mL}$ ) collected from healthy volunteers in EDTA tubes was centrifuged at $2500 \mathrm{rpm}$ for 10 min at $4{ }^{\circ} \mathrm{C}$. A volume of normal saline equivalent to that of the supernatant was used to dissolve the red blood cells. The volume of dissolved red blood cells obtained was measured and reconstituted as a $10 \% \mathrm{v} / \mathrm{v}$ suspension with isotonic buffer solution $(10 \mathrm{mM}$ sodium phosphate buffer, $\mathrm{pH}$ 7.4). The buffer solution contained $0.2 \mathrm{~g}$ of $\mathrm{NaH}_{2} \mathrm{PO}_{4}, 1.15 \mathrm{~g}$ of $\mathrm{Na}_{2} \mathrm{HPO}_{4}$ and $9 \mathrm{~g}$ of $\mathrm{NaCl}$ in $1 \mathrm{~L}$ of distilled water. Reconstituted red blood cells (resuspended supernatant) were used.

\section{Heat induced hemolysis and hypotonicity}

Samples of the extracts used were dissolved in an isotonic phosphate buffer solution on the one hand and in distilled water (hypotonic solution) on the other hand, at different concentrations $(31.25 ; 62.5 ; 125 ; 250$ and $500 \mu \mathrm{g} / \mathrm{mL}$ ). Sodium diclofenac was used as a reference. The negative control contained $1 \mathrm{~mL}$ of distilled water. A volume of $1 \mathrm{~mL}$ of erythrocyte suspension was added to each tube; the mixture was incubated at $54{ }^{\circ} \mathrm{C}$ for 20 min in a water bath for isotonic solutions and at $4{ }^{\circ} \mathrm{C}$ for $10 \mathrm{~min}$ for hypotonic solutions. After incubation, the tubes were centrifuged at $2500 \mathrm{rpm}$ for $10 \mathrm{~min}$ at $4{ }^{\circ} \mathrm{C}$ and the hemoglobin content of the supernatant was estimated using the spectrophotometer (Evolution 60S, USA) at $540 \mathrm{~nm}$. The percentage inhibition by the extract was calculated as follows:

\%Inhibition of hemolysis $=(1-\mathrm{DO}$ sample $/ \mathrm{DO}$ control $)$ $\times 100$.

Where DO sample=absorbance of the sample; DO control $=$ absorbance of the control.

The concentration of the extract for $50 \%$ inhibition $\left(\mathrm{IC}_{50}\right)$ was determined by the dose-response curve.

\section{Cytotoxicity of aqueous extracts on green frog tadpoles (Rana clamitans, latreille) Tadpole sampling}

Green frog ( $R$. clamitans) tadpoles were captured in July 2020 in a body of water near a river. Upon arrival at the laboratory, the tadpoles were placed in glass basins containing reconstituted water. For the lethal and sublethal tests performed, the reconstituted water was prepared according to the method, slightly modified, of [15] by adding to each liter of ionized water the following salts $1.25 \mathrm{~g} \mathrm{NaCl} ; 1.25 \mathrm{~g} \mathrm{KCl} ; 0.73 \mathrm{~g} \mathrm{CaCl}_{2}$. After a period of laboratory acclimatization, the organisms were subjected to the extracts. For the tests carried out, the water was 
completely renewed every 2 days and the tadpoles were fed with boiled spinach at a rate of $0.5 \mathrm{~g} /$ tadpole.

\section{Lethal and sublethal testing}

In order to choose the sublethal concentrations to which the tadpoles should be exposed, the lethal test was carried out [16]. During this test, 180 tadpoles distributed in 30 pools were exposed for $96 \mathrm{~h}$ to 10 concentrations distributed algebraically: control $(1.95 \mu \mathrm{g} / \mathrm{mL})$ and concentrations of $1.95 ; 3.9 ; 7.81 ; 15.62 ; 31.2 ; 62.5 ; 125 ; 250$; 500; $1000 \mu \mathrm{g} / \mathrm{mL}$. The experiments were performed in triplicate for each experiment. The number of dead tadpoles was counted after 24, 48, 72 and $96 \mathrm{~h}$ of exposure.

During the sublethal test, lasting 16 days, 60 tadpoles were divided into 9 pools and exposed to four concentrations, namely the control; $1.95 ; 3.9$ and $7.81 \mu \mathrm{g} / \mathrm{mL}$. At the end of each exposure period, the mass and stage of development of the tadpoles were determined [17].

The percentage mortality (corrected mortality) was obtained using the following formula.

$$
\mathrm{CM}=[\mathrm{M} 2-\mathrm{M} 1 / 100-\mathrm{M} 1] \times 100 .
$$

CM: \% corrected mortality; M2: \% mortality in the treated population; M1: \% mortality in the control population.

\section{Quantitative study of phenolic compounds}

Determination of total phenols The total phenol content of the crude extracts or fractions was determined by the method of Folin-Ciocalteu [18]. Absorbance was measured at $735 \mathrm{~nm}$. All experiments were carried out in triplicate and phenolic compounds were expressed as mg gallic acid equivalent (GAE)/100 g of extract.

Determination of total flavonoids Aluminium trichloride method was used to determine the flavonoid content and absorbance was measured after $10 \mathrm{~min}$ at $435 \mathrm{~nm}$. The flavonoid content was expressed as mg quercetin equivalent (QE)/100 $\mathrm{g}$ of extract [19].

Determination of the total tannins Tannin content was determined by using Standard method for determining the tannins in sorghum [20]. Absorbance was measured at $525 \mathrm{~nm}$ and tannic acid was used as a standard. The tannin contents were expressed in mg of tannic acid equivalent (TAE)/100 g of extract.

Determination of the total proanthocyanidins The determination of proanthocyanidins was carried out by the $\mathrm{HCl}$-Butanol method [20, 21]. Absorbance was read at $550 \mathrm{~nm}$ and apple procyanidin was applied as standard. Proanthocyanidin levels were expressed in apple procyanidins equivalent (APE).

Determination of the total alkaloids The determination of the total alkaloids was determined based on the reaction with bromocresol green [22]. The absorbance was measured at $417 \mathrm{~nm}$. All analyses were done in triplicate and results were expressed atropine equivalent per gram of extract.

\section{Statistical analysis}

The data were expressed as the mean \pm standard deviation (SD) of triplicate independent experiments and analyzed using one-way analysis of variance (ANOVA) and Student's t-test. $P<0.05$ was considered to be statistically significant.

\section{Results}

Antimicrobial activity of extracts of Guibourtia tessmanii (harms) J. Léonard

The results of the antimicrobial activity of the fractions and extracts of Guibourtia tessmanii were shown in Fig. 1a. The results showed the Gt $F_{2}$ fraction produces the largest zones of inhibition on bacterial strains such as P. aerugenosa, E. faecalis 103,907 CIP and B. cereus LMG 13569 BHI. Water-acetone extracts also showed very high inhibitions on $P$. aerugenosa, $E$. coli 105,182 $\mathrm{CIP}$ and S. thyphimurium. The Gt $\mathrm{F}_{1}$ fraction was shown to be more active on L. innocua LMG $135668 \mathrm{BHI}$ and $P$. aerugenosa. The extracts tested show very moderate inhibition on the majority of microbial strains. The zones of inhibition of the standards (Fig. 1b) are relatively larger than those of the extracts of Guibourtia tessmanii.

The MICs and MBCs of the Guibourtia tessmanii extracts on microorganisms have been summarized in Fig. 1c. The water, water-ethanol and water-acetone extracts exhibited bactericidal effects on the majority of bacterial strains with the exception of $P$. aeruginosa, E. coli 105, 182 and S. aureus ATCC 25293 BHI. The Gt F1 and Gt F2 fractions showed bactericidal effects on all the reference strains and a clinical strains ( $S$. thyphimurium). The Gt $\mathrm{F}_{4}$ fraction exhibited a bactericidal effect on $L$. innocua LMG 135668 BHI; S. aureus ATCC 25293 BHI; E. faecalis 103,907 CIP; B. cereus LMG 13569 BHI; S. dysenteria 5451 CIP; P. aeruginosa; S. enterica and S. thyphimurium.

\section{Antioxidant activities of Guibourtia tessmanii (harms) J. Léonard extracts}

The antioxidant activities of Guibourtia tessmanii extracts are summarized in Table 1. In the case of trapping the $\mathrm{DPPH}$ radical, the $\mathrm{IC}_{50}$ values vary from $6.92 \pm$ $0.48 \mu \mathrm{g} / \mathrm{mL}$ (water-acetone extract) to $16.64 \pm 0.20 \mu \mathrm{g} /$ 
(A)

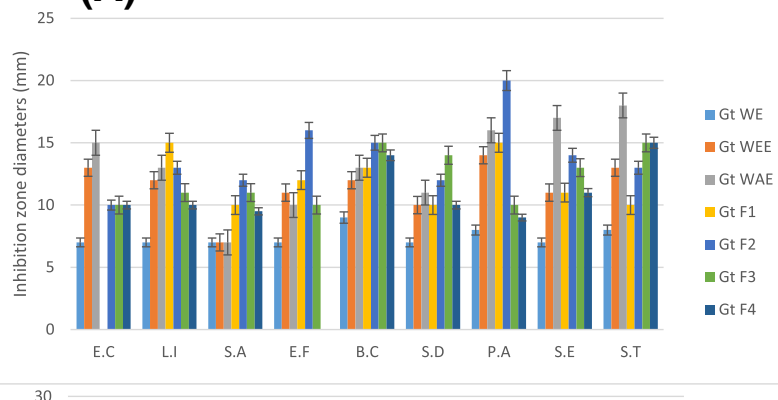

30
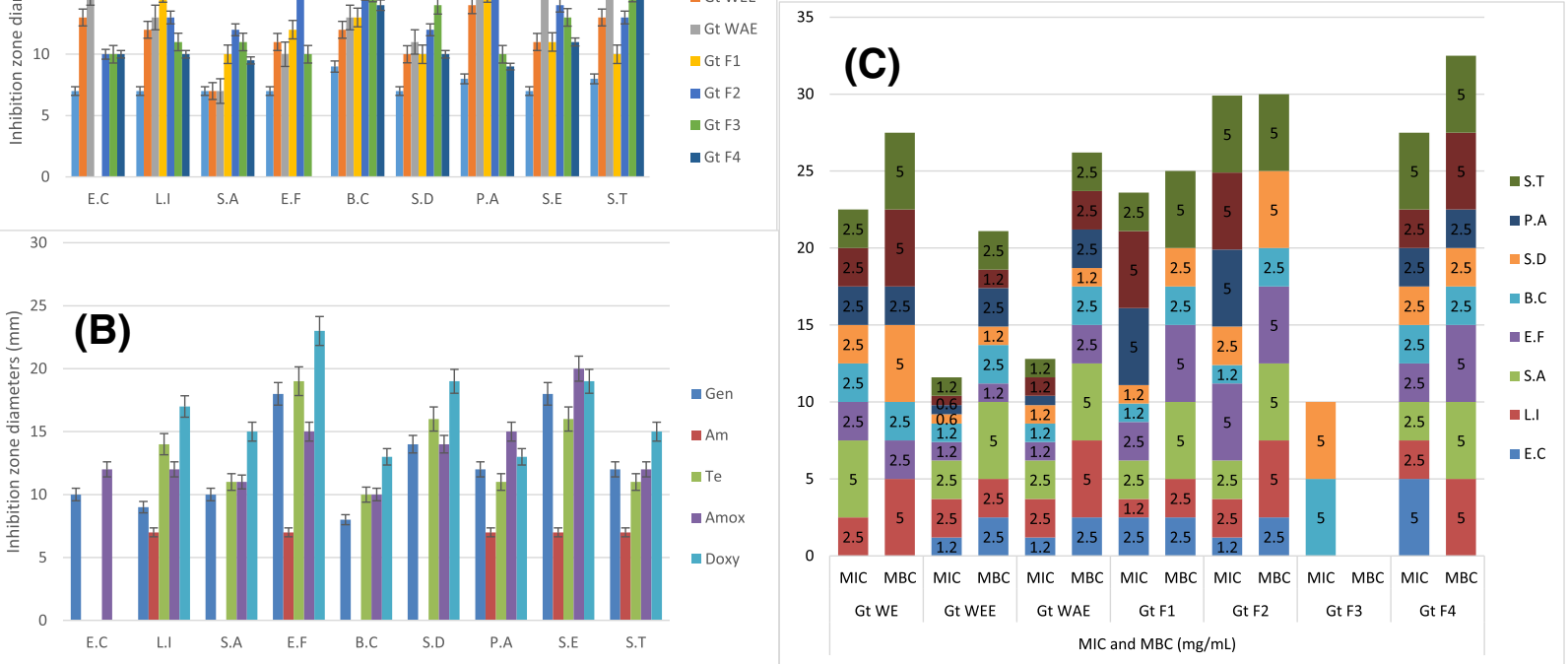

Fig. 1 Antimicrobial activity of total extracts and fractions from Guibourtia tessmanii. a Inhibition zone diameters of extracts, b Inhibition zone diameters of standards, c Minimum inhibitory concentration (MIC) and minimum bactericidal concentration (MBC) of plants extract. WAE = Wateracetone extract; WEE = Water-ethanol extract; F = Fraction; WE = Water extract; Gt = Guibourtia tessmanii J.Léonard; Gen = Gentamicin; Te = Tetracycline; Am = Ampicillin; Amox = Amoxicillin; Doxy= Doxycycline; E.C=Escherichia coli 105,182 CIP; L. I= Listeria innocua LMG 135668 BHI; S. A = Staphylococcus aureus ATCC 25293 BHI; E. F = Enterococcus faecalis 103,907 CIP; B. C= Bacillus cereus LMG 13569 BHI; S. D = Shigella dysenteria $5451 \mathrm{CIP} ; \mathrm{P} . \mathrm{A}=$ Pseudomonas aeruginosa; S. E = Salmonella enterica; S. T = Salmonella typhi

$\mathrm{mL}$ (water extract). The water-ethanol, water-acetetone extracts; and the fractions $G t F_{1}, G t F_{2}$ and $G t F_{3}$ did not show significant differences with vitamin $\mathrm{C}\left(\mathrm{IC}_{50}=\right.$ $7.12 \pm 0.60 \mu \mathrm{g} / \mathrm{mL})$ and Butylated Hydroxyanisole $\left(\mathrm{IC}_{50}=\right.$ $6.59 \pm 0.30 \mu \mathrm{g} / \mathrm{mL}$ ). However, the water extract and the Gt $\mathrm{F}_{4}$ fraction showed a significant difference with the standards (Vitamin C and Butylated Hydroxyanisole).

For the decoloration of ABTS, the oxidation was mainly inhibited by the water-acetetone, water-ethanol extracts; and the fractions $\mathrm{Gt} \mathrm{F}_{1}, \mathrm{Gt} \mathrm{F}_{2}$ and $\mathrm{Gt} \mathrm{F}_{3}$ compared to the standards which showed no significant difference with the aqueous extracts and the Gt $\mathrm{F}_{4}$ fractions.

\section{Anti-inflammatory activity of Guibourtia tessmanii (harms) J. Léonard extracts}

The anti-inflammatory activity study shows that the water and water-acetone extracts exhibited good

Table 1 Antioxidant activity of Guibourtia tessmanii J. Léonard extracts by DPPH and ABTS methods

\begin{tabular}{|c|c|c|c|}
\hline \multirow[t]{2}{*}{ Plant species } & \multirow[t]{2}{*}{ Extracts } & \multirow{2}{*}{$\begin{array}{l}\text { DPPH } \\
\mathrm{IC}_{50}(\mu \mathrm{g} / \mathrm{mL})\end{array}$} & \multirow{2}{*}{$\begin{array}{l}\text { ABTS } \\
I C_{50}(\mu \mathrm{g} / \mathrm{mL})\end{array}$} \\
\hline & & & \\
\hline \multirow[t]{7}{*}{ Guibourtia tessmanii } & Water-acetone extract & ${ }^{\mathrm{a}} 6.92 \pm 0.48$ & ${ }^{\mathrm{a}} 4.13 \pm 0.54$ \\
\hline & Water-ethanol extract & ${ }^{a} 7.74 \pm 0.63$ & ${ }^{\mathrm{a}} 4.02 \pm 0.79$ \\
\hline & Water extract & $b_{1} 16.64 \pm 0.20$ & ${ }^{b} 10.54 \pm 0.52$ \\
\hline & Fraction Gt $F_{1}$ & $\mathrm{a} 7.26 \pm 0.50$ & $\mathrm{a} 3.60 \pm 0.30$ \\
\hline & Fraction $\mathrm{Gt} \mathrm{F}_{2}$ & ${ }^{\mathrm{a}} 7.22 \pm 0.00$ & ${ }^{a} 3.26 \pm 0.40$ \\
\hline & Fraction $\mathrm{Gt}_{3}$ & $\mathrm{a} 8.50 \pm 1.10$ & ${ }^{\mathrm{a}} 4.50 \pm 0.60$ \\
\hline & Fraction $\mathrm{Gt} \mathrm{F}_{4}$ & 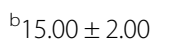 & $\mathrm{b}_{12.60 \pm 1.00}$ \\
\hline \multirow[t]{2}{*}{ Standards } & Vitamin C & ${ }^{a} 7.12 \pm 0.60$ & ${ }^{a} 5.01 \pm 0.55$ \\
\hline & Butylated Hydroxyanisole & ${ }^{\mathrm{a}} 6.59 \pm 0.30$ & ${ }^{\mathrm{a}} 4.26 \pm 0.25$ \\
\hline
\end{tabular}

In each column, the assigned values of different alphabetic letters $(a, b)$ indicate significantly different yields $(P<0.05)$ 
Table 2 Anti-inflammatory activity of Guibourtia tessmanii J. Léonard extracts

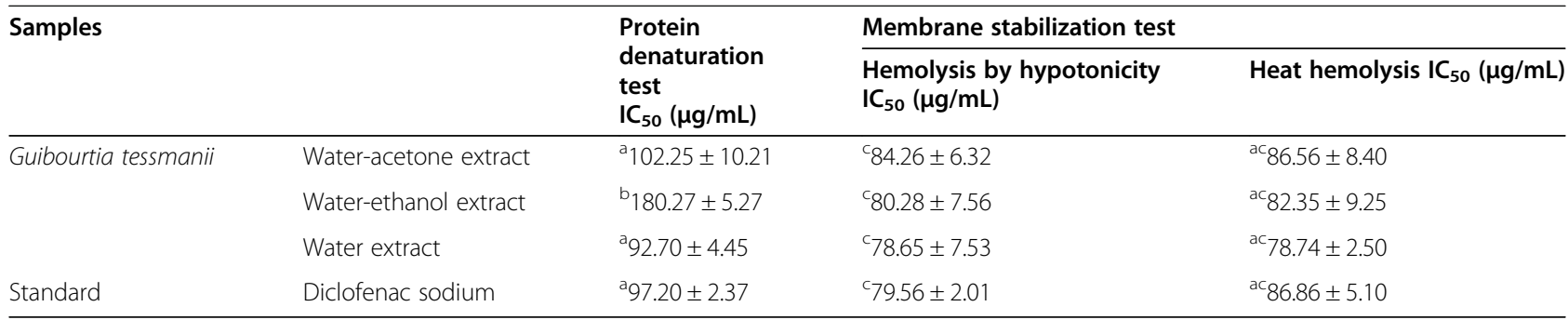

In each column, the assigned values of different alphabetic letters $(a, b, c)$ indicate significantly different yields $(P<0.05)$

inhibition of ovalbumin denaturation compared to the water-ethanol extract which indicated a significant difference from standards $\left[\left(\mathrm{IC}_{50}=97.20 \pm 2.37 \mu \mathrm{g} / \mathrm{mL}\right)\right.$ (Table 2)]. The hypotonic solution-induced hemolysis test shows that the three extracts studied exhibited good activities with $\mathrm{IC}_{50}$ s ranging from $78.65 \pm 7.53$ to $84.26 \pm$ $6.32 \mu \mathrm{g} / \mathrm{mL}$. For heat-induced hemolysis, all extracts exhibited very good antihemolytic activity with $\mathrm{IC}_{50} \mathrm{~S}$ ranging from $78.74 \pm 25.00$ to $86.56 \pm 8.04 \mu \mathrm{g} / \mathrm{mL}$. These results are not significantly different from the standard (Diclofenac sodium).

\section{Cytotoxicity of aqueous extracts of Guibourtia tessmanii (harms) J. Léonard \\ Lethal test}

The results of the lethal tests, presented in Table 3, show that the $\mathrm{LC}_{50}$ drops from $171.37 \pm 9.25 \mu \mathrm{g} / \mathrm{mL}$ to $58.25 \pm 7.21 \mu \mathrm{g} / \mathrm{mL}$ after 24 and $96 \mathrm{~h}$ of exposure. The rapid decrease in the $\mathrm{LC}_{50}$ value during the first two days reflects the variation in the number of deaths which was maximum after $24 \mathrm{~h}$ and $48 \mathrm{~h}$ of exposure (22 and 23 deaths respectively) while only 14 lethalities were recorded for the two other periods. After $96 \mathrm{~h}$ of exposure, no tadpole had survived at concentrations of $15.62 ; 31.2$; $62.5 ; 125 ; 250 ; 500$ and $1000 \mu \mathrm{g} / \mathrm{mL}$ while they were all alive in the basins containing only reconstituted water (controls) and the lowest concentrations of the aqueous extracts of Guibourtia tessmanii (1.95 and $3.9 \mu \mathrm{g} / \mathrm{mL}$ ).

\section{Mortalities during sublethal tests}

In the sublethal test, a high rate of mortality, relatively distributed among the selected concentrations, occurred in the tadpoles throughout the duration of the exposure
(16 days). In tadpoles exposed to $7.81 \mu \mathrm{g} / \mathrm{ml}$ of extracts, the first mortalities (12.5\%) were observed on the second day of exposure. From the ninth day, the mortality rate increased (25\%) until the 15th day (Fig. 2). Individuals exposed to 3.9 and $1.95 \mu \mathrm{g} / \mathrm{mL}$ aqueous extracts of Guibourtia tessmanii exhibited from days fourteenth and fifteenth a mortality rate of $12.5 \%$ until the last day of the study.

\section{Phenols and alkaloids content}

The total polyphenol content of the water- ethanol extracts, water-acetone and the $\mathrm{Gt}_{1} \mathrm{~F}_{1}$ fraction are significantly higher compared to the other extracts and fractions studied. The content of flavonoids is significantly more abundant in water-acetone extracts, in Gt $F_{1}$, Gt $F_{2}$ and $G t F_{3}$ fractions compared to other plant extracts. The water-acetone and water-ethanol extracts of Guibourtia tessmanii have the highest tannins and proanthocyanidins content. The alkaloid content is low for each extract compared to the content of phenolic compounds (Table 4).

\section{Discussion}

The antimicrobial activities of total extracts and fractions of bark extracts of Guibourtia tessmanii were demonstrated in this study. The results obtained show that the extracts have inhibitory effects on the growth of the majority of the bacterial strains tested. These inhibitions may be due to the presence of phenolic compounds in plant extracts [23]. The sensitivity of Enterobacteriaceae such as E. coli 105,182 CIP, E. faecalis 103,907 CIP, S. dysenteria 5451 CIP and S. enterica to the bark of Guibourtia tessmanii could

Table 3 Lethal concentration ( $\left(C_{50}\right.$ ) of aqueous extract of Guibourtia tessmanii for green frog tadpoles (Rana clamitans)

\begin{tabular}{|c|c|c|c|c|}
\hline \multirow[t]{2}{*}{ Species stage of development } & \multicolumn{4}{|c|}{$\mathrm{LC}_{50}(\mu \mathrm{g} / \mathrm{mL})$ depending on the duration of exposure } \\
\hline & $24 \mathrm{~h}$ & $48 \mathrm{~h}$ & $72 \mathrm{~h}$ & $96 \mathrm{~h}$ \\
\hline $\begin{array}{l}\text { Rana clamitan } \\
\text { Tadpoles }(0.91 \mathrm{~g})\end{array}$ & $\begin{array}{l}171.37 \pm 9.25 \\
\text { EP }\end{array}$ & $\begin{array}{l}61.99 \pm 5.02 \\
E P\end{array}$ & $\begin{array}{l}56.25 \pm 5.01 \\
\text { REG }\end{array}$ & $\begin{array}{l}58.25 \pm 7.21 \\
\text { REG }\end{array}$ \\
\hline $\begin{array}{l}\text { Bufo melanostictu } \\
\text { Tadpoles }(0.1 \mathrm{~g}) \\
{[27]}\end{array}$ & $\begin{array}{l}22.42 \\
E P\end{array}$ & $\begin{array}{l}19.81 \\
E P\end{array}$ & $\begin{array}{l}11.91 \\
\text { REG }\end{array}$ & $\begin{array}{l}8.18 \\
\text { REG }\end{array}$ \\
\hline
\end{tabular}




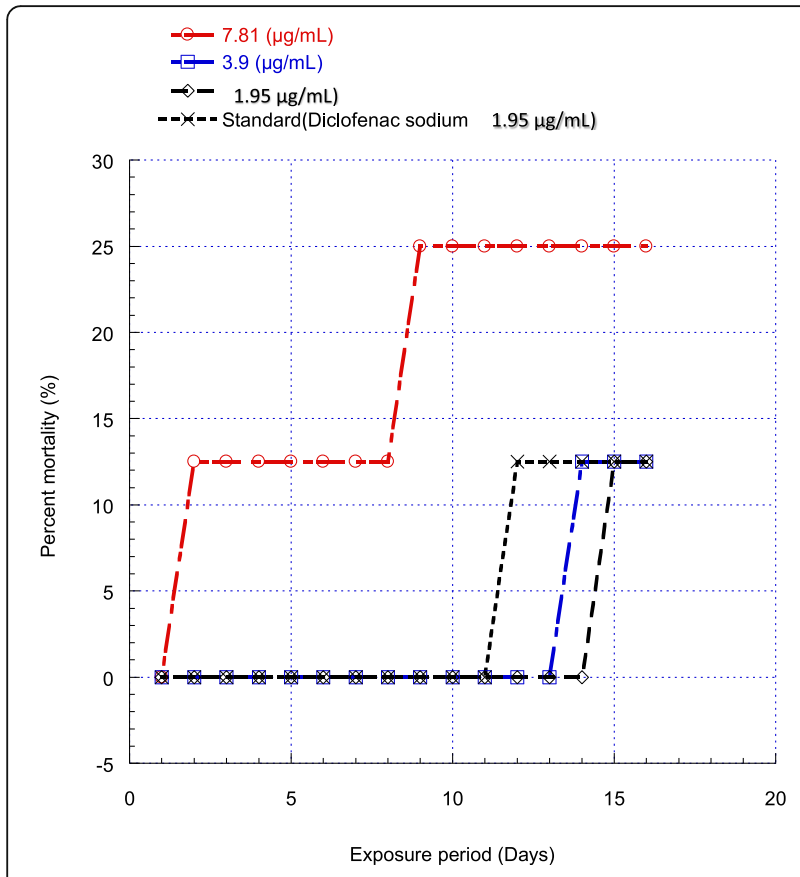

Fig. 2 Mortalities recorded during the sublethal test in tadpoles exposed to aqueous extract of Guibourtia tessmanii for 16 days

explain its use in traditional medicine in the treatment of diarrhea.

The high content of polyphenols may contribute to the antioxidant power of Guibourtia tessmanii. These antioxidants can act according to two major mechanisms, either by transfer of hydrogen atoms or by transfer of electrons [24]. Thus, the plant's ability to reduce free radicals DPPH and ABTS is relatively the same. The results of our study on antioxidant activity are compatible with the work of Fernández-Agulló [25].

The anti-inflammatory activity of Guibourtia tessmanii showed inhibition of protein denaturation for all aqueous and water-acetone extracts. As part of the study of the mechanisms of anti-inflammatory activity, the ability of the extract to inhibit protein denaturation was investigated. Indeed, according to the work of Chandra et al. [26], the extract of seeds of black cumin seeds tested showed an inhibitory effectiveness of thermal denaturation, as well as the stabilizing power of ovalbumin. Protein stabilization by black seed extracts involved polyphenols and their metabolites which acted as modulators of inflammation signaling pathways [26]. This corroborates the results found because Guibourtia tessmanii also having a high content of polyphenols also had anti-inflammatory activity. This antiinflammatory activity of plant extracts was confirmed by a test for stabilizing the membranes of erythrocytes. The results showed that at different concentrations of extracts, human erythrocyte membranes were protected against lysis and heat induced by hypotonic solution.

The extracts of Guibourtia tessmanii have shown effective biological activities. This study required the performance of cytotoxicity tests.

The results obtained show a variable sensitivity of frog tadpoles leading to low mortality rates from one concentration to another. The results also show that the cytotoxicity is progressive over time since an increase in mortality was recorded as the exposure time progresses, sometimes reaching a maximum mortality rate of $100 \%$ for the highest doses high.

The differences between the LC50 determined for $R$. clamitans and the values found in the literature for tadpoles and adults of other anuran species (Table 3) could be explained by the interspecific variations in sensitivity to toxic substances, the age of the exposed individuals and the physico-chemical conditions of exposure during the lethal tests. Differences in LC50 values can therefore be attributed to differences in sensitivity between stages of development and to interspecies variations in tolerance.

Table 4 Total phenolic content, total flavonoid content, total tannins content, total proanthocyanidins content and total alkaloid content of extracts from Guibourtia tessmanii J. Léonard

\begin{tabular}{|c|c|c|c|c|c|c|}
\hline Extracts & $\begin{array}{l}\text { Yield } \\
(\%)\end{array}$ & $\begin{array}{l}\text { TPC (mg GAE/100 g of } \\
\text { extract) }\end{array}$ & $\begin{array}{l}\text { TFC (mg QE/100 g of } \\
\text { extract) }\end{array}$ & $\begin{array}{l}\text { TTC }(\mathrm{mg} \text { TAE } / 100 \mathrm{~g} \text { of } \\
\text { extract) }\end{array}$ & $\begin{array}{l}\text { TPRC (mg APE } / 100 \mathrm{~g} \text { of } \\
\text { extract) }\end{array}$ & $\begin{array}{l}\text { TAC (mg AE/100 g of } \\
\text { extract) }\end{array}$ \\
\hline Gt WAE & 10.36 & a8 $357 \pm 20.25$ & $\mathrm{ab}_{1} 062.88 \pm 21.46$ & $a_{1} 1629.04 \pm 6.85$ & $\mathrm{ab}_{1} 708.44 \pm 0.37$ & ${ }^{c} 756.25 \pm 22,05$ \\
\hline Gt WEE & 5.04 & a8 $935.33 \pm 12.42$ & ${ }^{c} 781.63 \pm 15.25$ & $a_{1} 947.56 \pm 8.89$ & ${ }^{a b} 2308.44 \pm 2.96$ & ${ }^{b c} 508.36 \pm 23.57$ \\
\hline Gt WE & 0.86 & $\mathrm{~b}_{4} 206.44 \pm 15.67$ & ${ }^{c} 673.29 \pm 22.64$ & ${ }^{c} 797.93 \pm 5.43$ & ${ }^{c} 715.11 \pm 8.15$ & ${ }^{c} 659.10 \pm 33.25$ \\
\hline Gt $F_{1}$ & 0.75 & a7 $563 \pm 28.56$ & $\mathrm{ab}_{2} 265.50 \pm 10.56$ & $a_{2} 152 \pm 27.5$ & ${ }^{c} 786.25 \pm 18.50$ & ${ }^{c} 626.26 \pm 39.05$ \\
\hline$G t F_{2}$ & 0.82 & ${ }^{b} 6758 \pm 9.30$ & $\mathrm{ab}_{1} 1989.58 \pm 15.33$ & $a_{1} 525 \pm 17.5$ & $\mathrm{bc}_{525.12 \pm 16.20}$ & ${ }^{b c} 469.25 \pm 10.39$ \\
\hline$G t F_{3}$ & 0.67 & $\mathrm{ab}_{2} 598.80 \pm 17.35$ & $\mathrm{ab}_{1} 202 \pm 13.15$ & $\mathrm{bc}_{274.40 \pm 5.25}$ & ${ }^{b c} 258.42 \pm 10.55$ & ${ }^{b c} 226.39 \pm 29,00$ \\
\hline Gt $F_{4}$ & 0.51 & $\mathrm{ab}_{1} 952.50 \pm 20.20$ & ${ }^{c} 856.51 \pm 20.25$ & $b_{3} 329.60 \pm 9.56$ & $\mathrm{bc}_{25} 5.25 \pm 26.90$ & $\mathrm{bc}_{326,10 \pm 35.26}$ \\
\hline
\end{tabular}

TAC Total alkaloid content, TPC Total phenolic content, TFC Total flavonoid content, TTC Total tannins content, TPRC Total proanthocyanidins content, Gt Guibourtia tessmanii J. Léonard, WAE Water-acetone extract, WEE Water-ethanol extract, WE Water extract, $F$ Fraction, TAE Tannic acid equivalent, APE Apple procyanidins equivalent, $A E$ Atropine equivalent. In each column, the assigned values of different alphabetic letters $(a, b, c, d)$ indicate significantly different yields $(P<0.05$ 


\section{Conclusion}

Our work focused on highlighting the antimicrobial, anti-free radical, anti-inflammatory and cytotoxic properties of stem bark of Guibourtia tessmanii. The antimicrobial activity showed that the $G t F_{2}$ fraction produced the highest zones of inhibition with bactericidal effects on the majority of bacterial strains. Antioxidant activities revealed reducing responses of the ABTS and DPPH radicals. Protein denaturation and membrane stabilization tests also revealed anti-inflammatory activity comparable to diclofenac sodium. The cytotoxicity of the aqueous extracts showed relatively low mortality. This study validates the traditional use of Guibourtia tessmanii for the relief of various conditions.

\section{Acknowledgments}

The authors are very grateful to Shell Gabon for the financial support of the equipment at the USTM Biochemistry Research Laboratory (SG / CIS / SDM / $\mathrm{SA} / \mathrm{sa}$ grant $\left.\mathrm{n}^{\circ} \mathrm{77}\right)$.

\section{Authors' contributions}

All authors contributed equally. All authors read and approved the final manuscript.

\section{Funding}

None.

Availability of data and materials

Not applicable.

\section{Declarations}

\section{Ethics approval and consent to participate}

The study protocol was approved by the Ethics Committee of Gabon ( $\mathrm{N}^{\circ}$ 009 March 2013).

\section{Consent for publication}

Not applicable.

\section{Competing interests}

The authors declare that they have no competing interests.

Received: 23 November 2020 Accepted: 26 April 2021

Published online: 07 May 2021

\section{References}

1. Adjanohoun EJ, Ake Assi L, Chibon P, De Vecchy H, Duboze E, Eyme J, et al. Contribution aux études ethnobotaniques et floristiques au Gabon. Paris: Agence de coopération culturelle et technique; 1984. p. 294.

2. Madingou NK, Souza A, Lamidi M, Mengome L, Mba CEM, Bayissi B, et al. Study of medicinal plants used in the management of cardiovascular diseases at Libreville (Gabon): an ethnopharmacological approach. Int J Pharm Sci. 2012;3:111-9.

3. Troeger C, Blacker B, Khalil IA, Rao PC, Cao J, Zimsen SR, et al. Estimates of the global, regional, and national morbidity, mortality, and aetiologies of lower respiratory infections in 195 countries, 1990-2016: a systematic analysis for the global burden of disease study 2016. Lancet Infect Dis. 2018; 18(11):1191-210. https://doi.org/10.1016/S1473-3099(18)30310-4.

4. Basak S, Singh P, Rajurkar M. Multidrug resistant and extensively drug resistant bacteria: a study. J Pathog. 2016;2016:1-5. https://doi.org/10.1155/2 016/4065603.

5. Barton GM. A calculated response: control of inflammation by the innate immune system. J Clin Densitom. 2008;118:413-20.

6. Koutroubakis IE, Malliaraki N, Dimoulios PD, Karmiris K, Castanas E, Kouroumalis EA. Decreased total and corrected antioxidant capacity in patients with inflammatory bowel disease. Dig Dis Sci. 2004:49(9):1433-7. https://doi.org/10.1023/B:DDAS.0000042242.22898.d9.
7. Nankaya J, Gichuki N, Lukhoba C, Balslev H. Medicinal plants of the Maasai of Kenya: a review. Plants. 2019;9(1). https://doi.org/10.3390/plants9010044.

8. Rocha PDS, Paula VMB, Olinto SCF, Santos EL, Picoli-Souza K, Estevinho LM. Diversity, chemical constituents and biological activities of endophytic fungi isolated from Schinus terebinthifolius Raddi. Microorganisms. 2020;8(6). https://doi.org/10.3390/microorganisms8060859.

9. Obiang CS, Misso RLNM, Atome GRN, Ondo JP, Engonga LCO, Emvo EN. Phytochemical analyses, antimicrobial and antioxidant activities of stem bark extracts of Distemonanthus benthamianus H. Baill. And fruit extracts of Solanum torvum Sw. From Gabon. Asian Pac J Trop Biomed. 2019;9(5):20916. https://doi.org/10.4103/2221-1691.259001.

10. Blois MS. Antioxidant determinations by the use of a stable free radical. Nature. 1958;181(4617):1199-200. https://doi.org/10.1038/1811199a0.

11. Brand-Williams W, Cuvelier M-E, Berset C. Use of a free radical method to evaluate antioxidant activity. Food Sci Technol. 1995;28:25-30.

12. Erel O. A novel automated direct measurement method for total antioxidant capacity using a new generation, more stable ABTS radical cation. Clin Biochem. 2004;37(4):277-85. https://doi.org/10.1016/j.clinbiochem.2003.11.015.

13. Ngoua-Meye-Misso R-L, Sima-Obiang C, Ndong JDLC, Ndong-Atome G-R, Ondo JP, Abessolo FO, et al. Medicinal plants used in management of cancer and other related diseases in Woleu-Ntem province, Gabon. Eur J Integ Med. 2019;29:29. https://doi.org/10.1016/j.eujim.2019.05.010.

14. Shinde U, Phadke A, Nair A, Mungantiwar A, Dikshit V, Saraf M. Membrane stabilizing activity a possible mechanism of action for the anti-inflammatory activity of Cedrus deodara wood oil. Fitoter. 1999;70(3):251-7. https://doi. org/10.1016/S0367-326X(99)00030-1.

15. Broyles RH, Johnson GM, Maples PB, Kindell GR. Two erythropoietic microenvironments and two larval red cell lines in bullfrog tadpoles. Dev Biol. 1981;81(2):299-314. https://doi.org/10.1016/0012-1606(81)90293-1.

16. Russell $L$. Functional and structural analyses of mouse genomic regions screened by the morphological specific-locus test. Mutat Res-Fund Mol M. 1989;212(1):23-32. https://doi.org/10.1016/0027-5107(89)90019-5.

17. Rutkoski CF, Macagnan N, Kolcenti C, Vanzetto GV, Sturza PF, Hartmann PA, et al. Lethal and sublethal effects of the herbicide atrazine in the early stages of development of Physalaemus gracilis (Anura: Leptodactylidae). Arch Environ Contam Toxicol. 2018;74(4):587-93. https://doi.org/10.1007/s00244-017-0501-y.

18. Singleton $\mathrm{V}$, Orthofer $\mathrm{R}$, Lamuela-Raventós RM. Analysis of total phenols and other oxidation substrates and antioxidants by means of folin-ciocalteu reagent. Methods Enzymol. 1999;299:152-78. https://doi.org/10.1016/S0076-6879(99)99017-1.

19. Magalhães LM, Almeida MIG, Barreiros L, Reis S, Segundo MA. Automatic aluminum chloride method for routine estimation of total flavonoids in red wines and teas. Food Anal Methods. 2012;5(3):530-9. https:/doi.org/10.1007/s12161-011-9278-1.

20. Hagerman AE, Butler LG. Choosing appropriate methods and standards for assaying tannin. J Chem Ecol. 1989;15(6):1795-810. https:/doi.org/10.1007/BF01012267.

21. Ngoua-Meye-Misso RL, Sima-Obiang C, Ndong JDLC, Ondo JP, Ovono Abessolo F, Obame-Engonga LC. Phytochemical screening, antioxidant, antiinflammatory and antiangiogenic activities of Lophira procera a. Chev. (Ochnaceae) medicinal plant from Gabon. Egypt J Basic Appl Sci. 2018:5:80-6.

22. Patel RK, Patel JB, Trivedi PD. Spectrophotometric method for the estimation of total alkaloids in the Tinospora cordifolia M. and its herbal formulations. Int J Pharm Pharm Sci. 2015;7:249-51.

23. Behiry SI, Okla MK, Alamri SA, El-Hefny M, Salem MZ, Alaraidh IA, et al. Antifungal and antibacterial activities of Musa paradisiaca $L$ peel extract: HPLC analysis of phenolic and flavonoid contents. Processes. 2019;7(4). https://doi.org/10.3390/pr7040215.

24. Boulebd $\mathrm{H}$. Comparative study of the radical scavenging behavior of ascorbic acid, BHT, BHA and Trolox: experimental and theoretical study. J Mol Struct. 2020;1201:127210. https://doi.org/10.1016/j.molstruc.2019.127210.

25. Fernández-Agulló A, Pereira E, Freire MS, Valentao P, Andrade P, GonzálezÁlvarez J, et al. Influence of solvent on the antioxidant and antimicrobial properties of walnut (Juglans regia L.) green husk extracts. Ind Crop Prod. 2013;42:126-32. https://doi.org/10.1016/j.indcrop.2012.05.021.

26. Chandra S, Chatterjee P, Dey P, Bhattacharya S. Evaluation of in vitro antiinflammatory activity of coffee against the denaturation of protein. Asian Pac J Trop Biomed. 2012;2(1):S178-80. https://doi.org/10.1016/S2221-1691(12)60154-3.

27. Khangarot B, Ray P. Correlation between heavy metal acute toxicity values inDaphnia magna and fish. B Environ Contam Tox. 1987;3(8):722-6.

\section{Publisher's Note}

Springer Nature remains neutral with regard to jurisdictional claims in published maps and institutional affiliations. 